УДК 378.02:372.8:37.018.554(045)

DOI: $10.15587 / 2313-8416.2016 .64803$

\title{
FOREIGN LANGUAGE TEACHING FOR SPECIFIC PURPOSES: BASIC ASPECTS
}

\section{(C) S. Grynyuk}

The present article is an attempt to understand, analyse and provide an overall picture on basic aspects of English for Specific Purposes: its definition, scope, historical background, characteristics, types and aims. It also discusses the ESP teaching objectives, the role of ESP teacher and the training process to become an ESP teacher, the purpose of an ESP course and an ESP program.

We see a clear rationale, amongst the variety of contradicting views on ESP policy, in coming to an agreement finally that ESP is the teaching of English to the learners who have specific goals and purposes: professional, academic or scientific.

The article analyses the main roles and functions of teachers of foreign languages for specific purposes. It outlines the general tasks and responsibilities of higher education teachers whose professional activity is multispectral and multifunctiona; it also analyses the ESP courses and their specific features

Keywords: English for Specific Purposes, ESP definition, ESP evolution, ESP teaching objectives, ESP teacher, ESP teaching and learning, ESP course

У статті здійснено спробу проаналізувати, узагальнити та скласти повну картину щодо основ викладання іноземної мови за професійним спрямуванням. Досліджуваними аспектами виступають: історичне підтрунтя появи та закріплення відповідного конщепту у мовознавстві і методииі викладання іноземної мови, його дефініція, характеристики та різновиди іноземної мови за професійною складовою. У статті аналізуються основні ролі та функиї викладача іноземної мови за професійним спрямуванням; досліджується мета, завдання та зміст курсу іноземна мова за професійним спрямуванням

Ключові слова: іноземна мова за професійним спрямуванням (IПС), еволючія IПС, дефінічія ІПС, цілі, мета, завдання курсу IПС, роль та функиії викладача

\section{Introduction}

English for Specific Purposes (ESP) reflects the worldwide interest in the study of English. Among the factors influencing the creation of this academic subject are the following:

- the introduction of governmental mass education programs with English as the first or the foreign language;

- the need of English as a common medium of communication and a consequence of the growth of business and increased occupational mobility;

- the facilitation of access to scientific and technical literature.

ESP has developed its own methodology and its research draws on research from various disciplines. ESP has always been with needs analysis and preparing learners to communicate effectively in the tasks prescribed by their field of study or work situation.

2. Stating a problem. ESP: definition, evolution, types

From the the second half of the $20^{\text {th }}$ century, English for Specific Purposes has grown to become one of the most prominent areas of English foreign language teaching today. Long scientific debates in this domain and shared opinions amongst educators have resulted in defining ESP as: "...the area of inquiry and practice in the development of language programs for people who need a language to meet a predictable range of communicative needs". Therefore, English for Specific Purposes today presumes teaching of English as a foreign language regarding specific profession, subject or purpose.

Hutchinson and Waters [1] noted that two key historical periods breathed life into ESP. The first was the end of the Second World War bringing with it an “ ... age of enormous and unprecedented expansion in scientific, technical and economic activity on an international scale for various reasons, most notably the economic power of the United States in the post-war world, the role [of international language] fell to English". The second was the Oil Crisis of the early 1970s resulted in Western money and knowledge flowing into the oil-rich countries; the language of this knowledge became English.

The birth of ESP and its origin have been much discussed by the scientific elite and successfully led to stating three reasons common to the emergence of all ESP: the demands of a Brave New World, a revolution in linguistics, and focus on the learner [1]:

The first reason means the expansion of demand for English to suit specific needs of a profession. Whereas English had previously decided its own destiny; rather, it now became subject to the wishes, needs and demands of people other than language teachers.

The second reason is the developments in the filed of linguistics. The attention shifted from defining formal language features to discovering the ways in which language is used in real communication, causing the need for the development of English courses for specific group of learners.

Whereas traditional linguists describe the features of language, revolutionary pioneers in linguistics began to put accent on the ways in which language is used in real communication. Hutchinson and Waters point out that one significant discovery was in the ways that spoken and written English vary. This idea was taken foeward. If language in different situations varies, then tailoring language instruction to meet the needs of learners in specific contexts is also possible. 
The third reason is educational psychology. Learner's needs and interests have an influence on their motivation and effectiveness of their learning. Rather than simply focus on the method of language delivery, more attention was given to the ways in which learners acquire language and the differences in the ways language is acquired. Learners were seen to employ different learning strategies, use different skills, enter with different learning chart, and be motivated by different needs and interests. Therefore, focus on the learners' needs became equally paramount as the methods employed to disseminate linguistic knowledge. Designing specific courses to better meet these individual needs was a natural extension of this thinking [2].

\section{Literature review}

The analysis of theoretical literature concerning ESP phenomenon has shown that it sprang into being in 1950s and 1960s when there was an expansion of scientific, technical and economic activities on an international scale referring to the works of Dudley-Evans and St. John. It gradually developed into a multilayered complex language approach which primarily based on learners' specific needs required by their professions or occupations.

The area of linguistic interest labeled as ESP was proven to have a universal dimension through the concept of language for specific purposes and a languagespecific perspective through the insights explored into various European languages.

For the last decades, there have been conducted numerous studies on different aspects of ESP (T. DudleyEvans [3], T. Hutchinson [1], P. Strevens [4], H. Basturkmen $[5,6])$; the series of works are dedicated to the importance of learners' needs analysis and target situation analysis in the process of ESP teaching (T. Hutchinson [1], R. West, M. Long). Some works are devoted to ESP curriculum development (H. H. Stern [7], J. Ewer). The significant researches have been conducted on the aspects of discourse and genre analysis in ESP teaching and different approaches to the learning of ESP (T. Dudley-Evans [3, 8], T. Hutchinson [1], D. Biber, Ch. Candlin, N. Fairclough, A. Henry, T. Yakhontova, O. Synekop).

The problem of ESP is not new to Ukrainian higher educational system. Of great interest here are the researches dedicated to ESP courses, including the courses for business students and of information sciences (S. Dyudyakova), for students in travel and leisure management, for the students in engineering (I. Chirva), and for the students of medicine. For instance, Y. Bulakhova proposed integrated multimedia use while teaching students of information sciences, V. Strilets focused on teaching reading and writing, implementing a project to create a site with a focus on its content for those studying business.

Most English teachers in Ukraine who have been trained and prepared in the areas related to linguistic competence, literature and cultural knowledge but they were not prepared enough to effectively teach ESP courses alone to other professional fields such as science, engineering, or computer technology. Thus, the provision of a proper professional training for ESP teachers or practitioners in Ukrainian higher educational system and their professional adaptation to teaching ESP with the perspective of their sustainable development was the first step to the improvement of the current situation with teaching ESP in Ukraine.

\section{Main part}

Despite the time length ESP had in its disposal to mature, in the process of its becoming, there was confusion amongst the ESP community in defining and interpreting meaning that the educators attached to it. Thus, some described ESP as simply being the teaching of English for any purpose that could be specified. Others were more precise describing it as the teaching of English used in academic studies; or the teaching of English for vocational or professional purposes.

To lessen the weight of pressure and the ambiguity of the question meaning to have more or less clear idea of the discussed issue, an extended definition in terms of "absolute" and "variable" [9] characteristics was given.

Suggesting the absolute characteristics, ESP is designed to meet specific needs of the learners; it makes use of the underlying methodology and activities of the disciplines it serves; and it is centred on the language (grammar, lexis, register), skills, discourse and genres appropriate to these activities.

Considering the variable characteristics, ESP may be related or designed for specific disciplines. In specific teaching situations, it may use a different methodology from that of general English. It is generally designed for intermediate or advanced learners, as well as for adult learners, either at a tertiary level institution or in a professional work situation. Sometimes, it could be used for learners at secondary school level, depending on the need and expedience of the situation. Most ESP courses assume basic knowledge of the language system.

Due to the discipline or professional area when ESP takes place, we categorize it into: English for academic purposes (EAP), English for occupational purposes (EOP), English for vocational purposes (EVP), and English for medical purposes (EMP), English for business purposes (EBP), English for legal purposes (ELP), and English for sociocultural purposes (ESCP) (Belcher 2009) $[9,10]$.

English for Academic Purposes (EAP), involving pre-experience, simultaneous/inservice and post-experience courses, encompasses English for (Academic) Science and Technology (EST), English for (Academic) Medical Purposes (EMP), English for (Academic) Legal Purposes (ELP), and English for Management, Finance and Economics. English for Occupational Purposes (EOP), for the study in a specific discipline (pre-study, in-study, and poststudy) or as a school subject (independent or integrated), includes English for Professional Purposes (English for Medical Purposes, English for Business Purposes - EBP) and English for Vocational Purposes (Pre-vocational English and Vocational English). EOP refers to English for professional purposes in administration, medicine, law and business, and vocational purposes for non-professionals in work (language of training for specific trades or occupations) or pre-work situations (concerned with finding a job and interview skills) [9]. 


\section{ESP Teaching Objectives}

Stern $(1989,1992)$ [7, 11] distinguished four types of ESP teaching objectives: proficiency, knowledge, affective, and transfer. Proficiency objectives concern mastery of skills such as reading, writing, listening, and speaking. Knowledge objectives concern the acquisition of linguistic and cultural information, where linguistic knowledge objectives include language analysis and awareness of the systematic aspects of language, cultural knowledge objectives include control of socio-cultural rules i.e. mastery of the norms of society, values, and orientations and the ability to recognize culturally significant facts, knowing what is acceptable and what is not. Affective objectives concern the development of positive feelings toward the subject of study; they include attitudes toward attaining second language competence, socio-cultural competence, and language learning. Transfer objectives concern the ability to generalize from what has been learnt in one situation to other situations.

In its turn, Helen Basturkmen (2005) [6] describes the five broad objectives in ESP teaching:

1) revealing subject-specific language use;

2) developing target performance competencies;

3) teaching underlying knowledge;

4) developing strategic competence and

5) fostering critical awareness.

Revealing subject-specific language use is linked to the linguistic knowledge objective and to the cultural knowledge objective in Stern's (1992) categorization. Teaching oriented to this objective aims to show how English is used in the target environment and to impart to students the knowledge about it that has been revealed by linguistic research in the field. Developing target performance competencies can be described as an approach focused on developing the ability to perform the activities of an occupation and function to the standards expected of those employed in that occupation. She also adds that teaching oriented toward this objective presents language operationally in terms of what people do with language and the skills they need to do it. Courses are organized around core skills and competencies that are also subdivided into microskills and more specific competencies. This orientation can be categorized as a proficiency objective, according to Stern's classification (1992). Teaching underlying knowledge means that the ESP teacher should be aware of the fact that using a second or foreign language for workplace or study purposes requires not only linguistic proficiency and knowledge but also knowledge and understanding of work-related and disciplinary concepts. Developing strategic competence refers to a three-part model of specific-purpose language ability comprising language knowledge (grammatical, textual, functional, and sociolinguistic), background knowledge, and strategic competence (assessment of the external context and engaging a discourse domain). Douglas [12] argues that strategic competence acts as a "mediator" between the external situational context and the internal language and background knowledge that is needed to respond to the communicative situation. Strategic competence is the link between context of situation and language knowledge and can be defined as the means that enables language knowledge and content knowledge to be used in communication. Fostering critical awareness means in this context to help English language learners meet the demands and expectations of the target environment, to close the gap between the students' present state of skills and knowledge and the level required by members of the target environment. Instructions aiming at raising students' critical awareness would involve discussion how norms and communicative practices in the target environments become established, encouraging students to critique any negative aspects, and making them aware of ways to try to change or modify the situation so as to position themselves better in relation to it.

\section{The Role of the Teacher}

ESP has a lot in common with teaching of general foreign language. However, in both cases it is necessary to consider linguistic development and methodology; to have insights in contemporary ideas regarding the position and role of foreign language teachers as well as the position and the role of foreign language learners; to face new technologies offered as a means improving the process of teaching and learning Foreign Language for Specific Purposes.

In this context, the ESP teacher must fill many roles and acquire certain knowledge. Dudley Evans [3] describes the true ESP teacher as the one who performs five different roles; they are:

1) teacher;

2) collaborator;

3) course designer and materials provider;

4) researcher

5) evaluator.

Thus, he or she is responsible for organizing courses, setting learning objectives, establishing a positive learning environment in the classroom, and evaluating student progress. In the light of our problem, organizing courses means setting learning goals, transforming them into an instructional program with the timing of activities. This is, in actual flow, selecting, designing and organizing course materials, supporting the students in their efforts, and providing them with feedback on their progress. Setting goals and objectives means the arrangement of the conditions for learning in the classroom and setting longterm goals and short-term objectives for student's achievements. The knowledge of students' potential is central in designing a syllabus with realistic goals that takes into account the students' concern in the learning situation. Creating a learning environment means creating the atmosphere in the classroom for acquiring language proficiency by means of using the language in interaction with other speakers. Here the teacher should create an atmosphere in the language classroom, which encourages the students. Learners must be self-confident in order to communicate, and the ESP teacher bears the responsibility aiming in building the learner's confidence. Evaluating students sees a teacher as a source of information that helps students identify their language learning problems and find solutions to them, find out the skills they need to focus on, and take responsibility for making choices which determine what and how to learn. 
The first role as "teacher" is synonymous with that of the "general english" teacher. In terms of the ESP theory and practice, the ESP teacher must first work closely with field specialists to meet the specific needs of the learners and adopt the methodology and activities of the target discipline. The second role can emerge from such a collaboration that does not have to end at the development stage and can extend as far as provide teaching. When team teaching is not a possibility, the ESP teacher must collaborate more closely with the learners, who will generally be more familiar with the specialized content of materials than the teacher him or herself.

Both "general english" teachers and ESP teachers are often required to design courses and provide materials. ESP practitioners are obliged to develop original materials; it is here that the ESP teacher's role as "researcher" is especially important. The elaborated materials should provide the classroom audience with appropriate material background.

The final role as "evaluator" might possibly be the most neglected, however; few empirical studies, that test the effectiveness of ESP courses, have been made. They provided the education community with the results in this domain.

\section{Training of ESP Teachers}

Through training, ESP teachers are equipped with the necessary knowledge and tools to deal with their own students' fields of specialization. A professional ESP teacher must be able to shift from one professional area to another without being obliged to spend months on getting to be ready and started. He or she simply applies the necessary tools, frameworks, and principles of course design to new material. The material should always be authentic, up-to-date, and relevant for the students'specializations.

Bojović (2006) [13] argues that the majority of teacher training courses include four basic elements:

1. Selection process. It is necessary because not every human being would become an adequate language teacher. Potentially ineffective individuals should be discouraged from entering the profession by adequate pretraining or post-training selection procedures.

2. Continuing personal education. Teachers should be well-educated people. Minimum standards accepted for teachers vary from country to country as well as there are variations in how the trainee's personal education is improved.

3. General professional training as an educator and teacher. This element involves what all teachers need to know regardless of which subject they teach - the components are as follows:

1) Educational psychology, the study of child development, social psychology, and the principles of educational thought. The component intends to lead the trainee to understanding of the nature of education.

2) An outline of the organization of education in a particular country. It means that the teacher should be aware of the different kinds of schools, of normal and unusual pathways through educational network, of responsibility, control and finance, of sources of reform and change, of the main features of history of education in the country where he or she will teach.
3) An awareness of the moral and rhetorical function of the teacher: the formation of standards, character, enthusiasm.

4) Knowledge of, skill in, class management, discipline and handling of various groups of students.

5) Knowledge of, skill in, basic instructional techniques, and understanding teacher-learner interaction.

6) Acceptance of the fundamental need for the preparation of lessons.

7) Understanding the role of curriculum, syllabus and teaching materials.

8) A teacher should be committed to keeping in touch with the teaching profession.

4. Special training as a teacher of a foreign or second language. The complexity of the process, which constitutes the core of most teacher training courses, can be simplified if the distinction is made between three aspects of it. These are:

- the skills component including three different skills required by the teacher: a) adequate teacher's command of foreign language for class purposes;

- teaching techniques and classroom activities;

- the management of learning means teacher's skills in assessing the progress of each individual in the class and managing the classroom activities in the way that most able learners are not frustrated by being held back, while the slowest are not depressed by being left behind.

Basicly, ESP courses are of various types, depending on specific scientific field or profession, and have specific features. Carver identified common characteristics teachers need to pay attention to in the teaching process. Thus, the authour spoke on:

1) The authenticity of the materials means the use of authentic learning materials is possible if we accept the claim that ESP courses should be offered at an intermediate or advanced level. The use of such materials, modified by teachers or unmodified, is common in ESP, especially in selfdirected studies or research tasks. The students are usually encouraged to conduct research using a variety of different resources including the Internet.

2) Purpose-related orientation means the simulation of communicative tasks required by the target situation. The teacher can give students different tasks, for instance, to simulate the conference preparation, to involve the preparation of papers, reading, note taking and writing.

3) Self-direction means that ESP is concerned with turning learners into users. It is necessary for selfdirection that the teacher encourages students to have a certain degree of autonomy.

\section{The results of the research}

The concept of ESP is multispectral and multistrained. Its appearance has proved to be an apparent result and urgent necessity on the changes the science and society in general faced with due to drastic and global processes taken their place starting from the second half of the $20^{\text {th }}$ century.

Due to the professional area ESP is divided into: English for academic purposes, English for occupational purposes, English for vocational purposes, English for medical purposes, English for business purposes, 
English for legal purposes, and English for sociocultural purposes.

The scientists distinguished four types of ESP teaching objectives: proficiency, knowledge, affective, and transfer. The ESP teacher fills many roles; they are:

1) teacher;

2) collaborator;

3) course designer and materials provider;

4) researcher;

5) evaluator.

A professional ESP teacher is able to shift from one professional area to another without being obliged to spend months on getting to be started. He/she applies the necessary tools, frameworks, and principles of course design to new material.

ESP courses are of various types, depending on specific scientific field or profession, and have specific features: the authenticity of the materials, purpose-related orientation, and self-direction.

A number of research done in Ukraine in this context argues that the current state of ESP teaching and learning is in rather unsatisfactory condition with poor level results in a foreign language professional competence amongst the university graduates. Teaching ESP to university students certainly requires from a language teacher methodological skills, some subject-specific knowledge and also developed ability of analysis and adaptation of this knowledge and skills to a certain educational environment. It is vital that the community as a whole understands what ESP actually represents, and can accept the various roles that ESP teachers or practitioners need to adopt to ensure its success.

\section{Conclusion}

The present article study has provided insights into contemporary state, tendencies, trends, and approaches to define the concept of ESP with its basic features. The findings of the present research support previous studies on ESP teaching and learning and have provided a detailed analysis on ESP as a concept within an arrow of issues in linguistics and methodogy of teaching; thus, equipping the educators in the area of concern with perspectives providing a fruitful environment for ESP teaching and learning.

\section{References}

1. Hutchinson, T. English for Specific Purposes: A learner-centered approach [Text] / T. Hutchinson, A. Waters. Cambridge: Cambridge University Press, 1987. - 183 p. doi: $10.1017 /$ cbo 9780511733031

2. Abdelkareem, M. D. Teaching ESP in a Blended Learning Setting [Text] / M. D. Abdelkareem; An-Najah National University // Available at: http://www.qou.edu/english/ conferences/firstNationalConference/pdfFiles/abdelkareem.pdf

3. Dudley-Evans, T. Developments in English for Specific Purposes: A multi-disciplinary approach [Text] / T. Dudley-Evans. - Cambridge: Cambridge University Press, 1998. $-301 \mathrm{p}$.

4. Strevens, P. ESP after twenty years: A re-appraisal [Text] / P. Strevens; M. Tickoo (Ed.) // ESP: State of the art. SEAMEO Regional Language Centre, 1988. - P. 1-13.

5. Basturkmen, H. Developing Courses in English for Specific Purposes [Text] / H. Basturkmen. - Palgrave: Macmillan, London, 2010. - 157 p. doi: 10.1057/9780230290518
6. Basturkmen, H. Ideas and Options in English for Specific Purposes [Text] / H. Basturkmen. - London: Lawrence Erlbaum Associates, Inc., Publishers, 2005. - 183 p. doi: 10.4324/ 9781410617040

7. Stern, H. H. Issues and options in language teaching [Text] / H. H. Stern; P. Allen, B. Harley (Eds.). - Oxford: Oxford University Press, 1992. -404 p.

8. Johns, A. M. English for Specific Purposes: International in Scope, Specific in Purpose [Text] / A. M. Johns, T. Dudley-Evans // TESOL Quarterly. - 1991. - Vol. 25, Issue 2. - P. 297. doi: 10.2307/3587465

9. Mohammad, K. A. The ESP Teacher: Issues, Tasks and Challenges [Text] / K. A. Mohammad // English for Specific Purposes World. - 2014. - Vol. 15, Issue 42. - Available at: http://www.esp-world.info/Articles_42/Documents/Ahmed.pdf

10. Jendrych, E. ESP: How to design challenging tasks for adult learners [Text] / E. Jendrych, H. Wisniewska // Pixel. - Available at: http://conference.pixel-online.net/ICT4LL 2010/common/download/Proceedings_pdf/CLIL01-Jendrych,Wisniewska.pdf

11. Stern, H. H. Seeing the wood AND the trees: some thoughts on language teaching analysis [Text] / H. H. Stern; K. Johnson (Ed.) // The second language curriculum. - Cambridge: Cambridge University Press, 1989. - P. 207-221. doi: 10.1017/cbo9781139524520.015

12. Douglas, D. Needs Analysis and Curriculum Development [Text] / D. Douglas; B. Paltridge, S. Starfield (Eds.). Oxford: Wiley Blackwell, 2013. - P. 207-221.

13. Milevica, B. Teaching Foreign Language for Specific Purposes: Teacher Development [Text] / B. Milevica. Convention Center Bernardin Portorož, Slovenia, 2006. P. 487-793. - Available at: http://www.pef.uni-lj.si/atee/978961-6637-06-0/487-493.pdf

\section{References}

1. Hutchinson, T., Waters, A. (1987). English for Specific Purposes: A learner-centered approach. Cambridge: Cambridge University Press, 183. doi: 10.1017/cbo9780511733031

2. Abdelkareem, M. D. Teaching ESP in a Blended Learning Setting. Available at: http://www.qou.edu/english/conferences/firstNationalConference/pdfFiles/abdelkareem.pdf

3. Dudley-Evans, T. (1998). Developments in English for Specific Purposes: A multi-disciplinary approach. Cambridge: Cambridge University Press, 301.

4. Strevens, P.; Tickoo, M. (Ed.) (1988). ESP after twenty years: A re-appraisal. ESP: State of the art. SEAMEO Regional Language Centre, 1-13.

5. Basturkmen, H. (2010). Developing Courses in English for Specific Purposes. Palgrave: Macmillan, London, 157. doi: $10.1057 / 9780230290518$

6. Basturkmen, H. (2005). Ideas and Options in English for Specific Purposes. London: Lawrence Erlbaum Associates, Inc., Publishers, 183. doi: 10.4324/9781410617040

7. Stern, H. H.; Allen, P., Harley, B. (Eds.) (1992). Issues and options in language teaching. Oxford: Oxford University Press, 404.

8. Johns, A. M., Dudley-Evans, T. (1997). English for Specific Purposes: International in Scope, Specific in Purpose. TESOL Quarterly, 25 (2), 297. doi: 10.2307/3587465

9. Mohammad, K. A. (2014). The ESP Teacher: Issues, Tasks and Challenges. English for Specific Purposes World, 15 (42). Available at: http://www.esp-world.info/Articles_42/Documents/Ahmed.pdf

10. Jendrych, E., Wisniewska, H. ESP: How to design challenging tasks for adult learners. Pixel. Available at: http:// conference.pixel-online.net/ICT4LL2010/common/download/Proceedings_pdf/CLIL01-Jendrych,Wisniewska.pdf

11. Stern, H. H.; Johnson, K. (Ed.) (1989). Seeing the wood AND the trees: some thoughts on language teaching analysis. 
The second language curriculum. Cambridge: Cambridge University Press, 207-221. doi: 10.1017/cbo9781139524520.015

12. Douglas, D.; Paltridge, B., Starfield, S. (Eds.) (2013). Needs Analysis and Curriculum Development. Oxford: Wiley Blackwell, 207-221.
13. Milevica, B. (2006). Teaching Foreign Language for Specific Purposes: Teacher Development. Convention Center Bernardin Portorož, Slovenia, 487-793. Available at: http://www.pef.uni-lj.si/atee/978-961-6637-06-0/487-493.pdf

Рекомендовано до публікаиії д-р пед. наук Ковтун О. В. Дата надходження рукопису 17.02.2016

Svitlana Grynyuk, Candidate of Pedagogical Sciences, Associate Professor, Department of Foreign Philology, National Aviation University, Kosmonavta Komarova ave., 1, Kyiv, Ukraine, 03058

E-mail: Svetmoy7@mail.ru

УДК 378.22.016-0-51:78.01(477.53) «1921/1933»

DOI: $10.15587 / 2313-8416.2016 .63037$

\title{
МУЗИЧНО-ТЕОРЕТИЧНА ПІДГОТОВКА МАЙБУТНЬОГО ВЧИТЕЛЯ В ПОЛТАВСЬКОМУ ІНСТИТУТІ НАРОДНОЇ ОСВІТИ (1921-1933)
}

\author{
(C) Н. Ю. Дем'янко
}

Розкрито організаційні засади й особливості музично-теоретичної підготовки майбутнього вчителя в Полтавському інституті народної освіти в період з 1921 по 1933 рік, висвітлено діяльність видатного украӥнського педагога і музикознавия В. М. Верховиния, визначено зміст інтегрованого курсу «Мистецтвознавство (співи і музика)», щзо забезпечував музично-теоретичну, методичну, практичну інструменттальну, вокальну $і$ диригентсько-хорову підготовку студентів

Ключові слова: музично-теоретична підготовка, мистецтвознавство, теорія музики, знання, уміння, навички

In the article are considered the organizational grounds and peculiarities of musical and theoretical training of the future teacher in Poltava insitute of national education in the period from 1921 to 1933 year. It was provided by the department of art critisism that was headed in aforesaid period by the prominent Ukrainian teacher, musicologist, ethnographer, choreographer, conductor and composer V. N. Verchovinets. Within his programs of the integrated course „Art criticism (singing and music)" the students of school and pre-school faculties received knowledges on elementary music theory, Ukrainian music history, world music history, harmony, musical education methods and choral singing. The skills and abilities necessary for the future professional activity were acquired at practical and laboratory lessons on solfeggio, play on musical instruments (piano, violin), singing, direction, choral singing. The most talented students took part in exemplary student chorus of Poltava INE where their vocal, choral and direction mastery was formed

Keywords: musical and theoretical training, art critisism, music theory, knowledge, skills, abilities

\section{1. Ветуп}

На сучасному етапі інтеграції України в європейський освітній простір, модернізації системи вищої освіти, реалізації основних настанов «Національної доктрини розвитку освіти України у XXI столітті» значно актуалізуються проблеми підвищення ефективності навчально-виховного процесу, удосконалення професійної теоретичної та практичної підготовки майбутнього вчителя. Їх успішному вирішенню сприятимуть не лише поліпшення наукового та навчальнометодичного забезпечення, розробка й упровадження інноваційних педагогічних підходів і технологій, а й пізнання, всебічне осмислення і раціональне застосування прогресивного досвіду минулого, найкращих здобутків вітчизняної педагогіки.

\section{2. Постановка проблеми}

Музично-теоретична підготовка $\epsilon$ основою процесу формування професійних компетентностей вчителя музичного мистецтва. На різних етапах ро- звитку вітчизняної системи освіти вона зазнавала деяких змін і відзначалась певною специфікою. Значний інтерес, на наш погляд, викликають педагогічні традиції, що складались у процесі підготовки фахівців у Полтавському інституті народної освіти, починаючи 3 моменту його утворення (1921р.), особливості змісту музично-теоретичної підготовки, методів і форм організації навчально-виховного процесу, діяльності професорсько-викладацького складу тощо.

\section{3. Літературний огляд}

Проблеми становлення і розвитку національної системи освіти, методологічні, методичні, організаційні засади професійної підготовки вчителя, різноманітні аспекти мистецької та музично-педагогічної освіти в Україні досліджувались у монографіях Б. Года, О. Єрмака, П. Киридона (висвітлено історію Полтавського національного педагогічного університету імені В. Г. Короленка, його видатні досягнення 3 моменту заснування, напрями, умови й особливості 